\title{
PENCEGAHAN DAN PENANGGULANGAN MALARIA PADA MASYARAKAT DI KABUPATEN MAMUJU PROVINSI SULAWESI BARAT
}

\author{
Harpenas $^{1}$, Muh. Syafar ${ }^{2}$, Hasanuddin Ishak ${ }^{3}$ \\ ${ }^{1}$ Jurusan Keperawatan Poltekkes Kemenkes Mamuju, \\ ${ }^{2}$ Konsentrasi Promkes PPs FKM Universitas Hasanuddin, \\ ${ }^{3}$ Konsentrasi Kesehatan Lingkungan PPs FKM Universitas Hasanuddin
}

\begin{abstract}
The aim of the research is to give a description on the prevention and handling of malaria. The research used qualitative method with a phenomenology approach. The informants consisted of 11 native people of Mamuju and Trasnmigrants selected by using snow ball technique.The results of the research reveal that in general community diagnoses malaria based on trias of malaria which tends be treated by themselves. To prevent the bites of mosquitoes at night, the community use mosquitoes nets bought in the markets with their own money. Prevention activities on the occurrence of mosquitoes breeding done by hoarding/drainage for flooded area are generally good but in transmigration area and original area Mamuju they do not run well.
\end{abstract}

\section{Keyword: malaria, prevention, handling, hoarding, mosquito nets.}

\section{PENDAHULUAN}

Malaria merupakan penyakit menular yang disebabkan oleh parasit (protozoa) dari genius plasmodium, yang dapat ditularkan melalui gigitan nyamuk anopheles (Anies, 2006). Penyakit ini masih menjadi masalah kesehatan masyarakat di dunia termasuk Indonesia yang mempengaruhi tingginya angka kematian bayi, balita dan ibu hamil. Setiap tahun lebih dari 500 juta penduduk dunia terinfeksi malaria dan lebih dari 1.000 .000 orang meninggal dunia. Kasus terbanyak terdapat di Afrika dan beberapa negara Asia, Amerika Latin, Timur Tengah dan beberapa bagian negara Eropa (Atmawikarta, 2010).

$$
\text { Dalam rangka menekan }
$$

perkembangan malaria, berbagai upaya pada masyarakat telah dilakukan diantaranya pencegahan dan pengobatan malaria. Namun angka kejadian malaria di Kabupaten Mamuju cenderung fluktuatif, sedangkan kasus klinis terjadi peningkatan selama lima tahun terakhir. (Mamuju, 2007) Kebiasaan masyarakat untuk berada di luar rumah sampai larut malam yang akan memudahkan gigitan nyamuk. (James \& Chin, 2009) Masyarakat masih melakukan upaya pengendalian yang masih mengacu pada pengetahuan budaya dan kepercayaan, masih terdapat penderita malaria yang tidak mendayagunakan pelayanan professional, karena kurang memiliki pengetahuan dan tinggal di wilayah yang jauh dari tempat pelayanan kesehatan sehingga masih terdapat penderita malaria yang hanya mendayagunakan pelayanan kesehatan pribumi dan memutuskan untuk memanfaatan pelayanan kesehatan professional setelah penyakitnya tambah parah. (Azis, 2010).

\section{BAHAN DAN METODE Jenis Penelitian}

Penelitian ini merupakan penelitian yang menggunakan metode kualitatif dengan pendekatan fenomenologi, merupakan pandangan berfikir yang menekankan kepada focus pengalaman-pengalaman subjektif manusia dan atau berusaha memahami subyek dari segi pandangan mereka sendiri. (Moleong, 2000) Untuk memperoleh informasi tersebut dilakukan melalui wawancara mendalam dan observasi tentang perilaku pencegahan dan penaggulangan malaria pada masyarakat Mamuju khususnya di Daerah Asli dan Transmigrasi yang ada di Kecamatan Papalang kabupaten Mamuju Provinsi Sulawesi Barat. Instrument utama dalam penelitian ini adalah peneliti sendiri dan untuk memperlancar kegiatan penelitian digunakan alat bantu yaitu pedoman wawancara, alat perekam suara maupun perekam gambar, buku catatan dan lain-lain. Untuk menjamin keabsahan data, maka dilakukan tekhnik triangulasi sumber yaitu membandingkan data hasil pengamatan dengan hasil wawancara mendalam, membandingkan hasil wawancara mendalam dengan data sekunder sehingga didapatkan data yang valid dan akurat (Bungin, 2007). 


\section{Lokasi Penelitian}

Penelitian ini dilaksanakan di Kecamatan Papalang, khususnya pada daerah asli Mamuju (Desa Bonda dengan Daerah Transmigran (Desa Toabo) Kabupaten Mamuju. Pemilihan lokasi didasarkan bahwa Mamuju merupakan daerah endemis malaria yang berada pada zona merah yang memiliki penduduk transmigran dan penduduk asli.

\section{Informan Penelitian}

Populasi dalam penelitian ini adalah semua penduduk Asli dan Transmigran di Kecamatan Mamuju, yang pernah menderita malaria. Pemilihan informan dilakukan secara snow ball. Informan pada penelitian ini melibatkan 11 orang, 3 orang diantaranya adalah petugas kesehatan. Penentuan jumlah informan sebanyak 11 orang karena pada saat mencapai jumlah tersebut sudah dianggap telah memadai karena sudah mencapai taraf saturasi.

\section{Analisis dan Penyajian Data}

Analisis data pada penelitian ini yaitu dilakukan melalui reduksi data, pada tahap ini merupakan proses pemilihan, pemusatan, penyederhanaan, pengabtrakan dan transformasi data kasar yang ditemukan di lapangan. Dengan kata lain pada tahap ini dilakukan analisis untuk menggolonggolongkan, membuang data yang tidak perlu, mengarahkan dan mengorganisasi data, selanjutnya melakukan penyajian data yang telah dianalisis pada alur pertama dan kemudian disajikan dalam bentuk teks dan narasi yang terakhir melalui penarikan kesimpulan berdasarkan temuan di lapangan.

\section{HASIL DAN PEMBAHASAN}

Informan berjumlah 11 orang, Tiga diantaranya petugas kesehatan, dua tokoh masyarakat dan yang enam orang adalah masyarakat umum. Karakteristik berdasarkan umur informan, antara 26 - 64 tahun, 7 (tujuh) orang laki-laki dan 4 (empat) orang perempuan. Rata-rata informan pernah mengalami malaria. Latar belakang pendidikan informan, juga bervariasi mulai dari tidak tamat SD sampai S1 dan menurut asal daerah tempat tinggal, 6 (enam) informan orang berasal dari Desa Bonda (Daerah Asli Mamuju), dan 4 (empat) informan berasal di Daerah transmigran dari berbagai daerah yaitu Jawa Barat, Manado, Bali dan Gowa sebagai bidan Desa. Diantara 11 (sebelas) informan hanya tiga orang diantaranya berstatus Pegawai negeri Sipil (petugas kesehatan) dan yang lainnya adalah kepala Desa Toabo, Sekretaris Desa Bonda, petani, nelayan dan tukang.

\section{Gambaran Umum Malaria}

Kejadian malaria pada dasarnya mengalami penurunan bila dibandingkan pada tahun 80 an, namun hal itu sangat susah hilang dari lingkungan tempat tinggal mereka karena kondisi lingkungan sangat mendukung untuk terjadinya habitat nyamuk. Hal ini diketahui dari kutipan wawancara:

“...Malaria itu banyak tahun 80, karena pertama belum ada pustu yang dekat, sangat jauh bahkan berpuluh-puluh kilo baru ada..."(MI; 42, S1, 21 Mei 2011)

"...tidak ada peningkatan atau penurunan tergantung dari cuaca, biasa kalau istilah bara' itu merajalelah malaria...biasa karena hujan tempat-tempat sampah digenangi air, disitulah terjadi jentik..."(AD; 74 th, S5, 23 Mei 2011)

“...disinikan daerahnya masi banyak hutan, jadi masyarakat juga masi banyak kerja kebun selama saya disini banyak yang didiagnosa malaria... "( SR; 26 th, S6, 23 Mei 2011)

Malaria masih merupakan golongan penyakit yang masuk dalam sepuluh besar penyakit terbanyak di Puskesmas Topore. Berdasarkan data di Puskesmas didapatkan bahwa status AMI (Annual Malaria Incidence) pada daerah asli Mamuju masih berada pada zona kuning sedangkan pada daerah transmigran sudah berada pada zona hijau. (Papalang, 2011).

Terdapatnya perbedaan yang mendasar dari kedua Desa tersebut, disebabkan dari kondisi lingkungan. Dimana pada daerah asli Mamuju merupakan daerah pantai, perkampungannya masih tergolong kumuh disekelilingnya terdapat rawa-rawa yang ditumbuhi ilalang, empang yang kurang terurus merupakan tempat ideal untuk perkembangbiakan An. Sundaicus yang memiliki karakteristik suka beristirahat pada gantungan baju dan jelajah terbang cukup jauh yakni $3 \mathrm{~km}$ sehingga sangat memungkinkan untuk terjadi kontak dengan nyamuk. Dinding rumah terbuat dari papan yang disusun, lantai dari anyaman bambu sangat memungkinkan lebih banyak lubang untuk masuknya nyamuk ke dalam rumah. Disamping itu di daerah asli Mamuju pun masih terdapat hutan yang tidak 
jauh dari pemukiman penduduk merupakan habitat dari An. Balabacensis yang memiliki karakteristik lebih menyukai darah manusia ketimbang darah binatang (Munif, Amrul, \& Moch, 2010).

Sedangkan kodisi lingkungan pada Daerah transmigran lebih baik dibandingkan daerah Asli Mamuju. Parit-parit sudah dibangun secara permanen yang memungkinkan air dapat mengalir dengan lancar dan cepat, konstruksi rumah pada umumnya memiliki kawat kasa sehingga dapat meminimalisir masuknya nyamuk ke dalam rumah. Namun terdapat salah satu tempat yang sangat berpotensi untuk perkembangbiakan nyamuk yaitu kondisi perkampungan yang dikelilingi oleh sawah yang berteras dengan aliran air lambat, hal ini sangat memungkinkan sebagai tempat perindukan An. Acoitus. (Papalang, 2011) Salah satu hal yang menguntungkan pada daerah transmigran adalah sebagian penduduk utamanya transmigran dari Bali memiliki kandang ternak babi di belakang rumahnya, sehingga dapat meminimalisir gigitan nyamuk karena jenis $A n$. Acoitus lebih tertarik kepada darah ternak ketimbang manusia, namun dapat saja bergantiganti menggigit manusia maupun ternaknya.

Salah satu faktor yang menyebabkan malaria tidak bisa hilang pada lokasi penelitian karena pada umumnya masyarakat menganggap malaria bukan suatu penyakit yang serius dan penyakit yang perlu ditakuti karena tidak seorang pun penderita malaria yang berakhir dengan kematian atau kecacatan. NR dalam kutipan wawancara berikut ini:

“...malaria masih ada sampai sekarang... tp masyarakat kayanya tidak terlalu takut...karena mereka mengatakan kalau sudah minum obat langsung sembuh dan disini tidak ada orang yang meninggal gara-gara malaria katanya...dan kalau pun mereka ada gejala malaria, mereka masih tetap bekerja seperti orang sehat karena mereka menganggap kalau malaria keringat sudah kerluar maka hilang juga malarianya..."(NR; $27 \mathrm{th}, \mathrm{S10}, 25 \mathrm{Mei}$ 2011)

Malaria tidak akan menyebabkan kematian. Anggapan tersebut membuat mereka lengah dan kurang berkonstribusi dalam upaya pencegahan dan penaggulangan malaria. Padahal meskipun tidak akan menyebabkan kematian, akan tetapi dengan penyakit ini akan bisa menurunkan produktifitas kerja yang akan mengakibatkan kemiskinan. Pada umumnya jenis malaria yang ada di lokasi penelitian adalah malaria vivax, dimana malaria ini akan sembuh meskipun tidak dilakukan pengobatan secara benar, namun suatu saat akan mengalami kekambuhan kembali pada saat daya tahan tubuh menurun. Berbeda dengan malaria palsifarum, apabila pengobatan teratur akan mengalami kesembuhan, namun ketika penanganannya tidak benar akan mengalami kematian (Munif, Amrul, \& Moch, 2010).

\section{Diagnosa dan Pengobatan dini Malaria}

Pada umumnya informan mengenalnya dan mengakui bahwa penyakit ini dikenal sejak mereka dilahirkan. Oleh karena itu dengan sendirinya mendiagnosa diri mereka sendiri, meskipun belum ada konsultasi dengan petugas kesehatan tetapi ketika ada gejala sakit kepala, panas, dingin dan sebagainya, mereka sudah mengatakan bahwa dia sudah menderita malari. Berikut penggalan wawancara dengan beberapa informan:

“...kalau dia itu panas dingin dan menggigil...karena memang sudah begitu apanamanya, kepercayaan orang disini kalau sudah begini malariami namanya..." (MI; 42, S1, 21 Mei 2011)

“... asal maringimmi anna menggenggeng loppa towandi nasa'ding mauangbomi malaria..." (...asalkan terasa dingin dan mengigil tapi serasa panas juga bilangmaki lagi malaria...) (MS; 47, S2, 21 Mei 2011).

Berikut ini komentar sebagai petugas SR (Bidan Desa):

“...ada juga datang...bidan jangan-jangan saya malaria, karena dulu si..(menyebut nama tetangganya) begini juga: menggigil, demam, sakit kepala...dibilang bidan dulu dia malaria..." (SR; 26 th, S6, 23 Mei 2011)

Masyarakat dari dirinya sendiri sudah membangun persepsi bahwa yang namanya malaria berhubungan dengan adanya gejala sakit kepala demam dan menggigil. Dalam melakukan tindakan pengobatan pun sangat bervariasi, terkadang pemilihan fasilitas kesehatan itu merupakan alternative yang terakhir setelah pengobatan sendiri mulai dari minum obat warung sampai minum obat tradisional sudah dilakukan. Namun ada juga yang memilih pelayanan kesehatan sebagai alternatif pertama meskipun pada dasarnya dia 
menggabungkan dengan pengobatan tradisional dengan minum dau-daunan yang pahit-pahit.

Penemuan dan pengobatan malaria baik secara aktif (ACD) maupun pasif (PCD) merupakan salah satu kegiatan yang sangat penting dalam program penaggulangan malaria, karena kegiatan ini sangat menentukan keberhasilan dalam menurunkan kasus termasuk menekan atau mengurangi terjadinya Kasus Luar Biasa (KLB). (Hasyim \& Hamzah, 2008).

Pada umumnya masyarakat Informan mengaku kalau menderita malaria langsung mencari pengobatan, namun pola pengobatan yang dipilihnya bermacam-macam. Ada yang langsung ke fasilitas kesehatan, ada yang memilih obat tradisional dulu, ada juga yang mengobati sendiri dengan membeli obat warung dan ada juga yang menggabungkan yaitu minum obat tradisional dan sekaligus minum obat yang disarankan/ diberikan oleh petugas kesehatan saat berkonsultasi. Berikut kutipan wawancara beberapa informan:

“...Kalau saya, beli dulu obat di kios seperti reboquin, kalau belum sembuh saya ke pustu, kalau belum sembuh juga saya minum daun papaya...pilihan terakhir pustu/puskesmas..."(MI; 42, S1, 21 Mei 2011)

“... laomi tau di Puskesmas...tapi Mandundumi toitau daun papaya... biasa towandi maalli obat riboquin di warung..." "(...pergimiki di puskesmas... tapi kita minum juga daun papaya ... biasa tonji beli obat riboquin di warung...) "'(MS; 47, S2, 21 Mei 2011)

“...lari ke bidan ke pustu saya...dikasiin pil ..., ngak pernah kemana-mana dirumah saja sama suami paling pake minyak...minyak kelapa, minyak tawon biasa diurutkan, sakit semua badan..." (WS; 40 th, S7, 24 Mei 2011)

Informan yang memilih pengobatan ke fasilitas kesehatan, dalam meminum obat untuk mengatasi malaria juga sangat bervariasi, ada yang meminum sampai habis ada juga yang meminum hanya sampai gejalanya hilang dan membiarkan obatnya begitu saja, meskipun sebelumnya ditekankan oleh petugas kesehatan untuk menghabiskan. Berikut kutipan wawancara Informan:

"...dibiarkan saja obatnya, kalau udah sembuh..."(WS; 40 th, S7, 24 Mei 2011)
"...Mua molemi dipiosangammi dirundu ..." (“...kalau sembuhmi dihentikanmi diminum...") (MS; 47, S2, 21 Mei 2011)

"...dihabiskan obatnya, biar sudah sembuh kalau masih ada obat..." (SL;31 th, S8, 24 Mei 2011)

Sedangkan pengakuan petugas kesehatan, bahwa obat yang diberikan kepada masyarakat semuanya dihabiskan meskipun gejalanya sudah hilang. Berikut kutipannya:

"...biasanya kalau belum terlalu parah ya" dikasi obat di pustu saja tapi kalau tiga hari idak ada perubahan kami rujuk ke puskesmas...kalau kami disini biarpun kelihatan sembuh begitu kami tetap anjurkan untuk habiskan obatnya...dan mereka habiskan..."( SR; 26 th, S6, 23 Mei 2011)

Hal lain yang disampaikan oleh kepala Puskesmas Papalang, tentang kejadian malaria terkait dengan pengobatan:

“...ini juga di sini kita sulit bu' karena temanteman yang ditugaskan di Desa dengan seenaknya memberikan obat tanpa merujuk dulu kesini,...meskipun kadang diberi surat rujukan tetapi masyarakat sudah dikasi obat dan ternyata sudah hilang gejalanya, mereka sudah malas untuk datang melakukan tes darah..."( AM; 38 th, S11, 25 Mei 2011)

Banyak anggota masyarakat di beberapa daerah endemis malaria menganggap masalah penyakit sebagai masalah biasa yang tidak perlu dikwatirkan dampaknya. Anggapan tersebut membuat mereka lengah dan kurang berkonstribusi dalam upaya pencegahan dan penaggulangan malaria. Di Indonesia, mendiagnosis, mengobati dan merawat sendiri bila sakit merupakan hal yang biasa. Masyarakat telah terbiasa mengkonsumsi obatobatan yang dapat dibeli di warung tanpa resep dokter (Depkes, 2007). Pengobatan yang tidak benar akan mengakibatkan resistensi terhadap obat, yang mengakibatkan kejadian malaria setiap saat akan kambuh kembali pada saat daya tahan tubuhnya menurun (Prabowo, 2008).

\section{Pemakaian Kelambu}

Hasil analisis data juga menunjukkan bahwa salah satu cara untuk melakukan proteksi diri terhadap gigitan nyamuk anopheles sebagai penyebab malaria adalah dengan cara menggunakan kelambu pada saat tidur di 
malam hari ${ }^{16}$. Pada umumnya masyarakat di lokasi penelitian, mereka menggunakan kelambu meskipun hanya kelambu biasa yang dibeli di pasaran dengan uang mereka sendiri. Berikut kutipan wawancara:

“...hanya kelambu dipake dibeli sendiri...tidak ada pembagian, yang saya tau pembagiam masuk hanya raskin lain dari itu tidak ada... "(AD; 74 th, S5, 23 Mei 2011)

“...Andiappadiang, ...ma'bocoitau, jarangi todini andiang ma'boco... Maallitau, ... malam Mattunu oba nуати, тиа nandiang oba nуати y a marrambomi tau dinamboyang..." (“...belum ada...pake kelambu, jarang orang disini tidak pake... dibeli...malam bakar obat nyamuk, kalau tidak ada yaa kita bikin perapian di bawah kolong rumah...") (MS; 47, S2, $21 \mathrm{Mei}$ 2011)

Berikut pernyataan kepala pustu: “... pake kelambu...beli sendiri.,, tapii dengardengar akan ada pembagian untuk masyarakat miskin dan ibu hamil. Tapi ngga tau kapan dibagikan...kurang tau juga kak sumbernya yang jelasnya dinkes yang bagikan...selain itu paling bakar obat nyamuklah, dan ndak bisa juga menghindari karena petani..." (SR; 26 th, S6, 23 Mei 2011)

Kebiasaan menggunakan kelambu merupakan upaya yang efektif untuk mencegah dan menghindari kontak antara nyamuk Anopheles spp dengan orang sehat disaat tidur malam, disamping pemakaian obat penolaknyamuk. (Depkes, 2007). Karena kebiasaan nyamuk Anopheles untuk mencari darah adalah pada malam hari, dengan demikian selalu tidur menggunakan kelambu yang tidak rusak atau berlubang pada malam hari dapat mencegah atau melindungi dari gigitan nyamuk Anopheles spp. (Harijanto, 2010)

Hasil observasi di Puskesmas Papalang dan diperkuat oleh informasi dari kepala puskesmas yang mengatakan bahwa kelambu yang mereka terima sebanyak lima ribu dari GF yang akan dibagikan kepada masyarakat. Berikut kutipan wawancara:

“...minggu lalu datang, ...kelambu yang berinsektisida, tapi belum dibagikan ke masyarakat karena akan dilakukan pelatihan kader cara perawatan kelambu... yang datang 5000 lebih...untuk keluarga miskin dan ibu hamil menurut informasinya, tapi anehnya yang datang lebih banyak dari jumlah $K K$ di wilayah kami...ada 2 kelambumi $1 \mathrm{KK}$, disesuaikan jumlah anggota KKnya mungkin...(sambil tersenyum)" ( AM; 38 th, S11, 25 Mei 2011)

Kelambu dapat berperan untuk mencegah gigitan nyamuk, sehingga dapat disimpulkan bahwa penggunaan kelambu merupakan cara yang terbaik untuk mencegah kontak manusia dengan nyamuk yang dapat mengurangi atau mencegah terjadinya penularan malaria. Mengingat akan pentingnya peranan kelambu, maka oleh Global Found mencanangkan program pembagian kelambu yang berinsektisida utuk masyarakat miskin dan ibu hamil.

Kelambu berinsektisida yang telah diuji cobakan dari beberapa daerah mendapatkan beberapa hambatan dalam pemakaian seperti dengan adanya efek samping dalam penggunaan kelambu antara lain: panas, sesak napas, gatal dan lain-lain serta pemeliharaan kelambu yang kurang baik meskipun relative sedikit. Hal ini yang membuat kelambu sampai sekarang ini belum dibagikan kepada masyarakat, karena sebelumnya akan dilakukan pelatihan terhadap para kader bagaimana cara pemeliharaan kelambu tersebut.

\section{Penimbunan dan Pengaliran Genangan Air}

Hasil analiss data yang didapatkan di Lokasi penelitian, menunjukkan bahwa kegiatan masyarakat dalam pemberantasan tempat perindukan nyamuk seperti genangan air tidak dilakukan secara berkesinambungan, hal ini disebabkan kurang adanya kesadaran masyarakat dan mata pencaharian masyarakat pada umumnya adalah petani yang memiliki tingakat ekonomi dibawah rata-rata, sehingga mereka lebih mementingkan untuk bekerja di kebun dibandingkan harus tinggal membersihkan pari-parit sekeliling rumahnya. Berikut kutipan wawancara mendalam:

$$
\text { “...sekarang Sama sekali tidak ada }
$$
kegiatan pemberantasan, nanti kena baru langsung ke Puskesmas...Tahun 79 telah ada antisipasi dari pemerintah yaitu penyemprotan rumah melalui DDT, hanya itu yang saya tau...tahun 83 sudah tidak ada...karena sekarang itu yang diandalkan adalah posyandu, itupun hanya anak kecil saja yang diperiksa..."(AD; 74 th, S5, 23 Mei 2011)

"...menurut saya tidak ada... dibiarkan saja genangan air...”(MS; 47, S2, 21 Mei 2011) 
“...ndak ada sekarang kegiatan apa-apa ...dulu ada penyemprotan, Uhhh itu dulu waktu jamannya kita masi kecil masih pergi kejarkejaran... “( WS; 40 th, S7, 24 Mei 2011)

Hasil wawancara tentang upaya meminimalisir tempat perindukan nyamuk: “...sudah ada, seperti mereka turunkan ahliahli malaria, pemberian obat, membunuh tempat sarang-sarang nyamuk...menyemprot rumah... waktu saya masi kecil..." ( AR; 35 th, S4, 22 Mei 2011)

“...tidak ada, ada dulu mahasiswa-mahasiswa dari Makassar katanya calon-calon bidan rajin kerja bakti... pemerintah setempat, wuuu...tidak pernah mba', liatmi itu selokan kotoooorr tidak ada mau peduli sibuk semua kerja di kebun... "'(SL;31 th, S8, 24 Mei 2011)

tersebut

Pernyataan NR dan SR, tentang hal

...mungkin dari masing-masing individu... di sini kebanyakan mata pencahariannya sebagai petani jadi mereka lebih dominan ke sawah...itu tergantung dari kesadaran sendiri... (NR; 27 th, S10, 25 Mei 2011)

“...palingan yang dibersihkan selokan depan rumah mereka saja...biasanya setiap tahun diadakan penyemprotan dan tahun kemarin kayanya ada tapi tahun ini belum ada..."(SR; 26 th, S6, 23 Mei 2011)

Genangan air yang dijumpai di lokasi penelitian khususnya di daerah asli Mamuju adalah kolam-kolam, payau dan rawa-rawa yang tidak terurus merupakan tempat yang potensial untuk perkembangbiakan (breeding places) nyamuk An.Sundaicus dan An.subpictus . Keberadaan breeding places di sekitar rumah tentunya merupakan faktor risiko terjadinya penularan malaria (Anies, 2006) Berdasarkan penelitian dari Depkes diketahui bahwa faktor utama penularan malaria di pantai Ciamis adalah nyamuk An.sundaicus. Nyamuk jenis ini dapat ditemukan di kolam/ tambak yang tidak terurus. Jentik akan berkumpul pada tempat yang tertutup oleh tanaman, dan pada lumut yang mendapat sinar matahari. (McKenzie, James F, R Pinger, \& Robert dan Kotecki E Jerome, 2007).

\section{KESIMPULAN}

Terdapat keyakinan bahwa malaria merupakan masalah biasa yang mereka bisa tangani sendiri sehingga kerap kali mendiagnosa berdasarkan trias malaria yang cenderung diobati sendiri. Informan yang memilih pengobatan medis hanya sampai pada saat gejala hilang. Pada umumnya masyarakat dalam mencegah gigitan nyamuk, pada malam hari menggunakan kelambu meskipun kelambu yang mereka pakai adalah kelambu yang dibeli di pasaran dengan uang mereka sendiri, dan Kegiatan Pencegahan terjadinya sarang nyamuk melalui penimbunan/ pengaliran genangan air pada umumnya baik di daerah transmigran maupun daerah asli Mamuju belum berjalan.

Dibutuhkan penyebaran informasi tentang malaria sejak dini dengan memanfaatkan UKS, dibentuknya suatu Pos malaria Desa atau Juru Malaria Desa. Peningkatan program penggunaan kelambu di masyarakat selama tidur dan perlu adanya kerjasama lintas sektor untuk menggerakkan peran serta masyarakat dalam menghilangkan tempat perindukan nyamuk penular malaria.

\section{DAFTAR PUSTAKA}

Anies. (2006). Manajemen Berbasis Lingkungan. Jakarta: PT. Alex Media Komputindo.

Atmawikarta, A. (2010). Kebijakan Kesehatan dalam Pencapaian Target MDGs Kesehatan. Bandung: FK UNPAD.

Azis, A. (2010). Kabupaten Mamuju dan Mamuju Utara Endemis Malaria. Mamuju: Dinkes Sulbar.

Bungin, B. (2007). Analisi Data Penelitian Kualitatif. Jakarta: PT Rajagrafindo Persada.

Depkes, R. (2007). Pedoman Promosi Gebrak Malaria. 2007: Dikjen P2PL.

Harijanto. (2010). Malaria Treatment by Using Artemisinin in Indonesia. Acta Med Indones-Indones J Intern Med., Vol. 42 Number 1.

Hasyim, \& Hamzah. (2008). Manajemen Penyakit Lingkungan Berbasis Wilayah. Jurnal Manajemen Pelayanan Kesehatan, Vol. 11, No.2.

James, \& Chin, (. (2009). Manual Pemberantasan Penyakit Menular. Infomedika Jakarta: Edisi 17, Cet. III.

Mamuju, D. (2010). Profil Kesehatan Provinsi Sulawesi Barat. Mamuju: Dinkes Mamuju. 
Mamuju, D. K. (2007). Profil Kesehatan Provinsi Sulawesi Barat. Mamuju: Dinkes Mamuju.

McKenzie, James F, R Pinger, \& Robert dan Kotecki E Jerome. (2007). Kesehatan Masyarakat (Suatu Pengantar). Bandung: Buku Kedokteran (EGC).

Moleong, L. (2000). Metodologi Penelitian Kualitatif. Bandung: PT. Remaja Rosdakarya.
Munif, Amrul, \& Moch, I. (2010). Panduan Pengamatan Nyamuk Vektor Malaria. Jakarta: CV. Sagung Seto Cet. I.

Papalang, P. (2011). Profil 2008 - 2010. Papalang Mamuju: Puskesmas.

Prabowo, A. (2008). Malaria, Mencegah dan Mengatasinya. Jakarta: Puspa Swara. 